Politik Ekonomik Kuram 2018, Cilt 2(1), 19-34

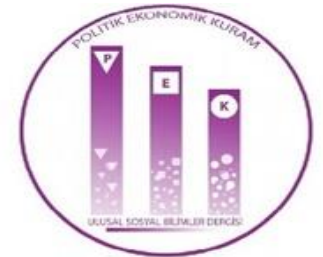

Politik Ekonomik Kuram Dergi Web Sitesi: http://dergipark.gov.tr/pek

Cilt 2(1) 2018

\title{
Bob Jessop, Post-Fordizm ve Devlet
}

\section{Mustafa Cem Ŏguz ${ }^{1}$}

\section{Makale Bilgileri}

Makale Geçmişi:

Makalenin Yüklendiği Tarih: 13.05.2018

Makalenin Kabul Edildiği Tarih: 27.05.2018

Jel Kodlar1: B29, B19, B59

Anahtar Kelimeler: Post-Fordizm, Hegemonya, Yönetimsellik, Yapısal Seçicilik ve Autopoiesis

\section{Özet}

Bob Jessop, devletin post-fordist üretim biçimi içindeki rolünü anlamaya çalışan araştırmacıların başında gelmektedir. Hali hazırda olmakta, gelişmekte bulunan bu üretim tarzının içinde yer alıp, ona dair yorumlarda bulunmak ilk elde yöntemsel bir zorluk taşımaktadır. Bu zorluktan dolayı Jessop, diğer disiplinlere başvurarak yeni üretim paradigmasının şekillendirdiği devleti açıklayabilecek kavramlar devşirmiştir: yönetimsellik, yapısal seçicilik ve autopoiesis. Bu yeni kavramlar ışığında devleti stratejik mücadele alanı olarak tanımlayan ve daimi olarak yeniden inşa edilen ilişkiler bütünü olarak gören Jessop, diğer devlet kuramcılarına göre oldukça farklı bir konuma yerleşmiştir. Onun için soyut, deney öncesi bir devlet formu yoktur, devlet hegemonik projelerin ve birikim stratejilerinin yarattı̆̆ bir formdur ve bu form post-fordist üretim tarzı ile çok daha belirgin bir hal almıştır

\section{Anahtar Kelimeler: Post-Fordizm, Hegemonya, Yönetimsellik, Yapısal Seçicilik ve Autopoiesis}

\section{Bob Jessop, Post-Fordism and State}

\section{Abstract}

Bob Jessop is a researcher who works to understand the new role of state in post-fordist era. To understand this role has a methodological difficulty due to post-Fordism's novelty and its incomplete nature. Because of this difficulty, Jessop appealed to other disciplines for new concepts to explain the new state that was reshaped by post-Fordism: governmentality, structural selectivity and autopoiesis. In the light of these concepts, Jessop describes the state as arena of power struggle and a relation form which always reconstructed over again. For him, there is not an a priori state form, state is a form which recreated by hegemonic projects and accumulation strategies and this form is become apparent due to post-fordist mode of production.

\section{Key Words: Post-Fordism, Hegemony, Governmentality, Structural Selectivity, Autopoiesis}

\footnotetext{
${ }^{1}$ Dr. Öğretim Üyesi, Niğde Ömer Halis Demir Üniversitesi, İ̈BF, Kamu Yönetimi Bölümü.
} 


\section{Giriş}

1970’ler ile birlikte kapitalizmin gelişiminde yeni bir evreye girildiği yargısı genel kabul görmüştür. Genel başlık olarak Post-kapitalizm diye anılan bu yeni dönem, araştırmacılar tarafından farklı nitelikleri göz önüne alınarak, farklı isimlerle tanımlanmıştır: Post-fordist, Post-endüstriyel, Post-modern, Fifth Kondratiev, Post-kolektif. Bu farklı adlandırmaların arkasındaki ortak nitelikler ise belli temalar üzerindeki vurgu artışıdır: vasıfsız fabrika emeği yerine, hüner (craft) emeğinin öne çıkış1; üretimde bant sisteminden, enformasyon ve bilgisayar teknolojilerine geçiş; emek sürecinin ve örgütlenme şemasının merkezsizleşmesi; seçme ve ürün çeşitliliği; pazarlama, paket ve dizayn; müşteriye gelirine göre değil, yaşam tarzına ve kültürüne göre yönelme; vasıfsız erkek emeği yerine, daha çok kadın emeğinden oluşan hizmet sektörü; uluslar arası iş bölümü ve ulus devlet denetiminden muaflık, vb. Bunların haricinde bu yeni kapitalist evrenin sosyal ve kültürel yaşama da farklı yansımaları olmaktadır; Ortodoks Marksistler, Post-kapitalizmi, sermayenin komünizmi olarak nitelerken, belli çevreler ise üretimde görülen bu farklılaşma ve çoğulluğun, kimlik alanında da bir özgürleşmeye neden olduğunu ifade etmektedir. Bir diğer görüş de yine bu bağlamda, Post-fordist tartışmayı geleceğin politikası olarak kucaklamaktadır, bu fikre göre Post-fordizm tartışmasının altında, daha demokratik, eşitlikçi ve neo-liberal muhafazakârlığa karşı daha insancıl bir siyasal proje arayışı yatmaktadır (Ash, 1995: 10-11).

Görüldüğü üzere Post-kapitalist dönem üzerine yapılan tartışmalar fenomenleri tespit düzeyinde ortak bir yargıya ulaşıyor gözükse de, bu fenomenlerin ne anlama geldiği ya da ne vaat ettiği konusunda farklı yorumlara açılmaktadırlar. Bu çalışmada tartışmalara fazla girilmeyecek ve Post-fordist emek örgütlenmesi ile bu üretim tarzının şekillendirdiği toplum ve devlet formu üzerine yoğunlaşılacaktır. Buradaki odağımız ise çalışmaları ile bu yeni hegemon üretim tarzını masaya yatıran ve buradan yola çıkarak son dönemin en çok tartışılan devlet nosyonuna ulaşan Bob Jessop'un fikirleridir. Poulantzas, Gramsci, Foucault gibi isimlerin tesiri altında günümüz devletine bakan Jessop, içinde bulunduğumuz üretim paradigması ve toplumsal formasyonu literatürde en ayrıntılı ele alan düşünürdür, bu nedenle onun eserlerine dair yapılacak bir inceleme bu ilişkiyi anlamamız bakımından elzemdir.

$\mathrm{Bu}$ gaye ile öncelikle çeşitli araştırmacıların post-fordizme yaklaşımlarını ele alınacak ve ve nasıl bir toplum ve devlet tasarımına ulaştıkları ortaya konulacaktır. Hemen ardından Jessop'un 
Devlet düşüncesi kısa bir şekilde özetlenip, onun post-fordizm hakkındaki analizlerine geçilecektir. Çalışma kısa bir değerlendirme ile son bulacaktır.

\section{Post-Fordism}

Literatürde daha çok Charles Sabel ve Piore'in yaklaşımları çerçevesinde karşımıza çıkan esneklik kavramı, istihdam hacim ve biçimlerinde, ürün niteliğinde, emek piyasalarında, iş pratiklerinde, teknolojide, organizasyon formunda Fordist rijit düzenlemelerin ve standardizasyonun esnetilmesi, yumuşatılması anlamına gelmektedir. Kısacası emek sürecinde ve onun birinci dereceden bağlantılı olduğu tüm mevcut yapılarda bir değişimi, Fordist kalıplardan uzaklaşmayı ve bilgisayarlı teknolojinin verdiği olanaklarla fordizm öncesi iş kalıplarının birleştirilmesini ifade etmektedir (Belek 1999: 66-67).

Sabel ve Piore'nin genel tezi esnek uzmanlaşma (Flexible Specialization) ile ikinci endüstriyel döneme geçildiğidir. Bu endüstriyel dönemlerden ilki yüzyılın başından itibaren yükselen ve Keynesyen politikalarla güç kazanan kitlesel üretim (mass production) dönemidir. Standart ürünler yaratmak için yarı vasıflı işçiler tarafından, ürün amaçlı makineler ile sürdürülen bu üretim, 1970’lerin kriz ortamı ile yerini esnek uzmanlaşmaya bırakmıştır. Bu dönemi belirleyen 2 etken vardır: ilki düzenleyici kurumların iflası ile oluşan talepteki durağanlık ve belirsizlik. Talebin azalması ve sürdürülemez hale gelmesi, standart olmayan, kaliteli, raf ömrü kısa ürünlere ilginin artmasını doğurdu. İkinci etken ise teknolojide esnek üretimi destekleyecek yeni gelişmelerin yaşanmasıdır. Öyle ki, teknolojideki bu atılım sayesinde (özellikle bilgisayarlı üretim), ürün çeşitliliği artarken, ölçek olarak küçük firmalarında rekabet yetisi kazandığı görülmektedir. İşte Piore ve Sabel için 70'ler ile başlayan bu dönem endüstri mantığında yeni bir dönemi göstermektedir (Ash, 1995: 14-15).

Piore ve Sabel'e göre esnek uzmanlaşma sadece yeni bir emek düzenlemesi ya da yeni bir üretim paradigması değildir, fakat açıkça insanın yabancılaşmasının aşılması için önemli bir adımdır. Zira onların nazarında günümüzde, Taylorist-Fordist emek ve teknoloji örgütlenmesinin ortaya çıkardı̆̆ $\breve{g}_{1}$ emeğin makineye tabiiyet durumu tamamen değişmiştir. Artık, emek gücü makinenin kullandığı, parçalanmış, kendi emeği ve emek aracı üzerinde kontrolünü yitirmiş emek gücü değildir. Tam tersine makine insanın kontrolüne girmekte, böylece insanın yaratıcılığ 
Piore ve Sabel, insani emeğin yaratıcılığının geliştirilmesi ve yabancılaşmanın aşılması bağlamlarında bilgisayar teknolojisine ve yeni emek düzenlemelerine karşı son derece iyimser bir yaklaşıma sahiptirler (Belek, 1999: 78).

John Tomaney, Piore ve Sabel'in ortaya attığ 1 “esnek uzmanlaşma teorisi”ne eleştiriler getiren ve bunun kapitalist sömürü rejiminin bir başka veçhesi olduğunu iddia eden bir araştırmacıdır. Tomaney için esnek uzmanlaşma yeni bir ortodoksidir ve makalesinde bu ortodoksinin arkasındaki iyimser bakışı eleştirmektedir. Bu iyimser bakış şudur: günümüzde yaşanan teknik değişim, işverenle, işçileri daha fazla işbirliği ilişsileri kurmaya yönlendirmektedir; kitlesel üretim sisteminde emek birincil önemini kaybetmişken, esnek örgütlenme ile emeğin önemi tekrar gündeme gelmiştir. Tomaney bu iyimser görüşe karşı argümanlarını şu şekilde sıralar: bilgisayar teknolojilerinin sahaya girmesi, hüner emeğini (craft) yeniden ortaya çıkardı mı? Cevap nettir, sürecin bilgisayarlaşması, zanaat üretimini canlandırmaktan ziyade büyük ölçekli üretimleri güçlendirmiş ve emeğin yaratıcılığını ve öncelliğini tamamen ortadan kaldırmıştır. Tomaney, esnek örgütlenme ile işin niteliğinde bir değişim olduğunu kabul etmektedir; fakat bunun post-fordizm gibi bir kopuş adını hak edemeyecek kadar evrimsel bir değişim olduğunu belirtmektedir. Zira bu dönüşümün işçiye özerklik kazandırmaktan ziyade, fordist rejimin teknoloji ile daha sıkı bir ilişki kurmasına yol açtığını belirtmektedir. Tomaney’in bir diğer eleştirisi ise post-fordizmin, vasıflı işlerin, iş bölümü içine nasıl konumlandırılacağı konusunu cevapsız bırakmasıdır. İşte tüm bu nedenlerle Tomaney, Fordizm-Postfordizm dikotomisinin gerçeği yansıtmayan hayali bir kurgu olduğunu dile getirmektedir; zira fordist dönem olarak anılan dönemde, makineleşmesine rağmen işin örgütlenmesi konusunda fazla rasyonelleşmeye gitmeyen birimler her daim olmuştur, bu nedenle yeknesak bir fordist dönemden bahsedilemez. Bir diğer unsur da, taylorizm ve mekanikleşmenin, homojen, vasıfsız bir işçi güruhu yarattığ iddiasıdır; ancak gerçekte kompleks, çeşitli ve ortak bir emek biçimi yaratmıştır. Bunun vasıfsız olduğu iddiası, post-fordist tezin, kendini kopuş olarak koyma çabasından kaynaklanmaktadır. Tomaney için fordizm ile postfordizm arasındaki yegane fark, fordizmin, sermayenin taleplerine uygun olarak geliştirilmiş olması, post-fordizmle ise buna ek olarak mikroelektronik teknolojideki yenilikleri takip etmesidir; arada bir paradigma değişimi yoktur (1995: 179).

Alain Lipietz ise Postfordist üretim tarzını demokrasinin gelişimi açısından kucaklayan araştırmacılardandır. Lipietz’e göre 20. yy’ın ikinci yarısında işçi sınıfının başarısı olarak 
yükselen Fordist uzlaşı, organizmacı anlamda teknik sürecin meyvelerinin yeniden dağıtımını hak olarak sunmuştur; fakat gücü teknokratlara devrederek, işletmenin ve toplumun hiyerarşik karakterini de güçlendirmiştir. Fordizmin krizi ise daha az organizmacı olan bir durgunluğa yol açan liberal-üretken paradigmayı doğurmuştu. Ancak bu paradigma da her ne kadar inisiyatifi öne çıkarmış olsa da dayanışmayı ve demokrasiyi yok sayarak toplumsal refahı iğdiş etmiştir. Lipietz işte bu noktada Postfordist paradigmayı demokratik bir alternatif olarak ortaya sürmektedir. Bu alternatif, organizmacı sistemi uzlaştırır, hiyerarşileri indirger, demokrasiyi işletmeye ve firma düzeyine doğru yayar. Aynı zamanda üreticilerin kolektif müzakerelerine, istihdamın tam değil, ama dinamik garantisine, boş zamanın artmasına dayanan bu alternatif Lipietz'in gözünde "refah devletinden, refah toplumuna" doğru bir geçişi ifade etmektedir (1992: 144-146).

Lipietz'e göre Fordizm'den sonra gelişen bireyci akıma karşı Fordist sol çaresiz kalmıştı; çünkü girişimsel ruhu ve dayanışmayı nasıl bir araya getireceğini bilmiyordu. Zira fordizm dayanışmanın sadece devlet tarafından sağlanılabileceğine inanıyordu ve işçiler ile vatandaşların inisiyatif almasını ihmal ediyordu. Bu noktada Lipietz, insiyatif ve dayanışma arasında kurulacak bir ittifakın günümüzün ekonomik problemlerini aşacağına inanmaktadır. Bunun için ekonomik birimlerin lokalleşmesi ile demokratik kurumların da paralel olarak lokalleşeceğini ve böylece inisiyatif ve dayanışmanın daha kolay gerçekleşebileceğini iddia etmektedir:

Bir tarafta kaynaklar, know-how teknikler, girişim ruhu ve imgeler, diğer tarafta tatmin edilmemiş ihtiyaçların keşfi ve sosyal uzlaşım. Bu tabloda artık insanlar masa başına salt ücret görüşmek için geçmeyecek; para akışlarının ötesinde, maddi ve insani gerçekler yükselecektir. Ekoloji, finans ekonomisini kontrol ederken, refah devleti de, refah cemaatine/toplumuna dönüşecektir (Lipietz, 1995: 358).

Hiyerarşik olmayan bir organizmayı ifade eden bu Postfordist paradigma, Lipietz için Fordist üretim krizine ve onun sonucu olan baskıcı siyasal ve toplumsal sisteme alternatif öneriler getirmektedir (1995: 346):

1. İnsanların iş sürecinde, kendi ürünleri üzerinde daha büyük bir kontrole sahip olmas1, 
2. Özgür yaratıcılığın yükselmesi, tüketimin ve ücretli emek ilişkilerinin gerilemesi,

3. Üretimde ekolojik tekniklerin tercih edilmesi,

4. Hiyerarşinin azaltılması, cinsiyete ve etnik kimliğe dönük ayrımcılığın ortadan kalkmas1,

5. Ulusal kolektivite içindeki dayanışma formlarının, maddi kaynakların merkezi yeniden dağıtılmasından, kendince organize olan örgütlere sübvansiyon olarak dönüşümü,

6. Klasik halk demokrasilerinin, daha organik ve daha az temsile dönük formlara evrilmesi.

\section{Bob Jessop'un Devlet Analizi:}

Bob Jessop'un çalışmaları 80'lerden sonra gelişen ve hegemonik bir güç olan Yeni Sağ'ın devlet ile ilişkisini ele almaktadır. Bu birikim rejiminin ne sanıldığı gibi devleti küçültüp, işlevsiz kıldığını ne de doğrudan doğruya devleti belirlediğini söyleyen Jessop bu karmaşık toplumsal ve ekonomik ilişkilerin devlet ile hali hazırda ne gibi bir ilişki içinde olduğunu göstermeye çalışmıştır. Jessop bu ilişkiyi analiz ederken, Marksist kuramdaki hâkim paradigmalar olan sınıf-kuramsal ve sermaye-kuramsal yaklaşımların cenderesinden çıkmayı ve devleti çok daha farklı bir perspektiften ele almayı tercih etmiştir. Yapısalcı geleneği takip eden düşünür, kapitalist devleti de biçimsel olarak belirlenmiş bir toplumsal ilişki alanı olarak tanımlamaktadır. Devlet ona göre, birikim stratejileri ve hegemonya projelerinin oluşturulmaya çalışıldığı stratejik bir alandır, bir diğer deyişle devlet, sınıflar arası mücadelenin değil kuramsal olarak kurgulanmış strateji ve projelerin mücadele alanıdır.

Devlet konusunda Poulantzas'ın “toplumsal bütünlüğü sağlayan görece özerk yapı” yorumunu takip eden Jessop "devletin saf kapitalist üretim tarzı değil, toplumsal formasyon temelinde yer alacağını ve sınıf ilişkileri kadar sınıf dışı ilişkileri de barındıracağını” söyleyerek, hem sınıf hem sermaye merkezli görüşlerin dışında bir pozisyon almıştır (Jessop, 2005a: 44-45). Onun için devlet ve iktisat ilişkisi zorunlu ve kendiliğinden değil, fakat stratejik mücadeleler yoluyla oluşsal olarak gerçekleşir; birikim stratejileri ile şekillenen iktisadi alan ile hegemonya projeleri ile şekillenen siyasal alan karşılıklı olarak birbirlerini koşullandırmakta ve bir ilişki biçimi olarak devlet ortaya çıkmaktadır. 
Jessop'un çalışmalarında en önemli kavram olarak karşımıza çıkan strateji, onun devlet yaklaşımına da adını vermiş ve stratejik-kuramsal yaklaşım ortaya çıkmıştır. Stratejiyi verili bir yapı içinde geçerli olabilecek alternatiflerin oluşturulması anlamında kullanan düşünür, yapıyı da eski stratejilerin kristalleşmiş hali olarak kabul ederek, sınıf ve sermaye kutuplaşmasını aşabilmiştir (Jessop, 2005b: 132). Birikim stratejisi ile belli bir üretim tarzına denk gelen tek bir sermaye rejimi olamayacağını, alternatif sermaye mantıklarının olabileceğini söylerken; hegemonya stratejileri ile de devletin, kendiliğinden tek bir tarzda değil, fakat sonsuz çoğulluk içinde şekillenebileceğini söylemektedir (Jessop, 2005b: 123). Zira Jessop'a göre her türlü yapının içinde onunla diyalektik bir tarzda ilişki kurarak gelişen bu stratejilerin ardında Ortodoks Marksizm'de olduğu gibi global bir özne yoktur, bu diyalektiğin içinden dönemsel olarak öne çıkan ve hegemonyayı kuran olumsal özneler vardır:

Birikim stratejilerini, düzenleyici mekanizmaları veya hegemonya projelerini planlayan başarıyla uygulanmasını garanti altına alan global bir özne yoktur. Bunun yerine eylemleri az ya da çok eş güdümlü olan ve diğer toplumsal güçler tarafindan az veya çok direnişle karşılaşılan, öteki toplumsal güçlerin stratejilerini kendileri için hem engelleyici hem teşvik edici olarak bir yapısal bağlamda takip eden farklı özneler buluruz (Jessop, 2005b: 139).

Jessop bu farklı öznelerin çoğulluğunu söylem fikri ile de açmak ister ve yapıya karşı geliştirilen söylemsel strateji ve kimlikleri öne çıkarır. Buradan düşünür şöyle bir yargıya varır, en önemli özneler, en önemli kimlikler ve temel talepler sınıf terminolojisi ile açıklanmaya ihtiyaç duymaz (Güney, 2004: 369). Öyle ki, ona göre siyasal alanda oluşan hegemonya, iktisadi belirlenimden uzak, mevcut yapısal formasyon içinden, ona karşı geliştirilen söylemsel stratejiler ile ortaya çıkmaktadır. Bu bağlamda devlet artık ne bütün toplumsal güçlerin eşit oranda ele geçirip kendi amaçları için kullanabilecekleri doğal bir araç, ne de belli bir sınıfın çıkarına hizmet eden akılcı hesapçı bir öznedir. Devlet yapısal olarak belirlenmiş stratejik ilişkiler bütünü olarak bir ilişki biçimidir (Güney, 2004: 368).

İktisadi ve siyasi alanları birbirinden ayıran ve bu alanların oluşumunda strateji kavramına başvuran düşünür, devlet konusunda da bu iki alanın yapısal eşleşmesi sonucunda ortaya çıkan ilişkiler bütününü öne çıkarmaktadır. Jessop’un devleti hem siyasal alanın hem iktisadi alanın 
oluşturduğu bir ilişki biçimi olarak yorumlaması, devleti sermayenin ya da sınıfın bir aracı olmaktan çıkararak, birikim rejimi ile hegemonyanın bir ürünü konumuna getirmektedir. Bir başka deyişle, devlet sınıflar arası mücadelenin değil, kuramsal olarak kurgulanmış strateji ve projelerin mücadele alanıdır, bu nedenle sermaye asla otonomiye haiz değildir, hem kendi içinde hem de siyasal alanla ilişskisinde daimi olarak şekillendirilmekte, yontulmaktadır, zira devlet, Jessop'a göre "saf kapitalist üretim tarzı değildir, toplumsal formasyonun temelinde yer alan ve sınıf ilişkileri kadar, sınıf dışı ilişkileri de barındıran” bir ilişki biçimidir. Ve yine bu nedenle, devlet-inşası bir kez olup biten bir süreç değil, belirli fakat değişken kurumsal sınırlar içinde sürekli olarak yenilenmesi gereken bir süreçtir. Dolayısıyla devlet, sorunsuz bir özne ya da araç olarak değerlendirilemez: her durumda siyasi eylem içinde ve siyasal eylem yoluyla inşa edilen a prior bir forma sahip olmayan stratejik bir alandır (Jessop, 2005b: 144-147). Bu stratejik alan ulusal ve uluslararası ölçekte ekonomik gelişme ile ilgili olan birikim stratejisi ve ekonomi dışı ulusal-popüler gayelerin peşinde koşan hegemonya projesi'nin örtüşmesinin, birbirlerini şekillendirmesinin alanıdır.

Jessop'un devlete ve birikim rejimlerine dair yaptığı bu analiz, gerçeklikte Yeni Sağ'ın Kapitalizmin kronik krizlerine karşı geliştirdiği devleti ve sınıfsal güçleri bir hegemonya projesi altında birleştirme yeteneği olarak karşımıza çıkan yönetişim projesini anlamayı hedeflemektedir. Düşünür için yönetişim, küresel kapitalizm çağında iktisadi ilişkiler ile diğer toplumsal düzlemler arasındaki bağlantıyı kurgulamada merkezi öneme sahip analitik bir araçtır. Jessop toplumsal ve iktisadi yaşamı teleolojik bir belirlenim içinden okumaz, daha ziyade "olumsal zorunluluk" içinden okumaktadır; zira ona göre yaşamı belirleyen tek bir etken yoktur, aksine yaşam tesadüflerin ve çoğullukların alanıdır. Bu çoğulluklar ve belirsizlikler alanı küreselleşme ile daha da yükselmiş, siyasal ve iktisadi alanın yönetilebilirliği temel problem haline gelmiştir. Jessop, çağımızda bu önemli ve yeni problemlerin çözülemediği ve yönetilemediği gibi, ne devletin hiyerarşik planlaması ile ne de piyasa dolayımlı anarşi ile bunun çözülemeyeceğini söylemektedir. Bu nedenle küresel çağda toplumsal hayat, ancak iktisadi ve siyasi alandaki öznelerin karşılıklı etkileşimleri olan yönetişim ile idame ettirilebilir (Güney, 2006: 160-161). Zira yeni-liberalizm de, hem birikim rejiminin içsel problemlerini hem de toplumsal hayattaki problemleri aşmakta piyasaya mutlak anlamda güvenememekte ve sürekli ekonomi dışı aktörler ile bir diyalog arayışına gitmektedir. Bu diyalog arayışı Post-fordist rejimde en açık halini almış ve toplumsal yaşamın hemen hemen her alanına sirayet etmiştir. 


\section{Bob Jessop ve Post-Fordizm:}

Düzenleme Okulu'nun temsilcisi olan Bob Jessop için Fordizm'den Postfordizme geçiş hem ekonomik düzenleme alanında bir değiş̧im, hem de buna bağlı olarak sosyal ve politik düzende bir değişimdir. Ve düşünür bu değişimin, devletin form ve işlevleri üzerindeki etkisi ile ilgilenmektedir. Jessop'un birinci iddiası fordist modelle uyumlu Keynesyen refah devletinden, post-fordizm ile uyumlu Schumpeteryan çalışma devletine doğru bir eğilim içinde olduğumuzdur. İkinci iddiası ise ulus devlet ve kapasitesinin içinin oyulduğu ve bunların ulus üstü, lokal ve bölgesel perspektiflere göre yeniden örgütlendiğidir.

Jessop bu iki iddiasını tanıtlayabilmek için Fordizmi ve Postfordizmi tanımlamaktadır: bir üretim süreci olarak Fordizm, karmaşık tüketim ihtiyaçlarının, bir üretim bandı üzerinde yarıvasıflı işçiler tarafından kitlesel üretimidir. Ancak bu iddia bir Fordist ekonomide tüm işçilerin doğrudan kitlesel üretime katıldıkları anlamına gelmemektedir, Fordist üretim hegemon üretim tarzıdır. Makroekonomik büyüme olarak Fordizmin ise üretimin kendini ayakta tutabilmesi ve istikrara sahip olabilmesi için yaşamsal bir döngüye ihtiyacı vardır; kitlesel üretime dayanmalı, ölçek ekonomisi sayesinde üretkenlik artmalı, üretkenliğe bağlı olarak gelirin artması, yükselen ücretlere tabi olarak talebin artması, tam çalışma kapasitesine bağlı olarak karın artması, kitlesel üretim teknolojilerine dönük yatırımların artması. Ekonomik düzenlemenin sosyal boyutu olarak Fordizm ise şu ayaklar üzerinde yükselmektedir: tekel fiyatlaması, sendika faktörü ve toplu mücadele, üretkenlik gelişimine endeksli ücretler, fiyat enflasyonu, talebin korunabilmesi için para emisyonu, kredi politikaları, büyümenin devamı için emek ve sermaye arasındaki çatışmaların devlet tarafından kontrolü ve yönetimi. Fordizm bir diğer veçhesi de standart ürünlerin üretilmesi ve tüketilmesidir: merkezden belirlenen ürün standard1, üretim band1 üzerinden akan süreç ve kitlesel tüketim. Görüldüğü gibi Fordizm toplumsal yaşamın birçok boyutunu birden belirleyen bir üretim modudur, Jessop bu nedenle ortak bir tanıma gitmeye ihtiyaç duyar ve Fordist üretimi, sermaye birikiminin ekonomik düzenlemeci modu olarak tanımlar (1995: 254).

Sermaye birikiminin ekonomik modu olarak Fordizm ile Keynesyen refah devleti arasında karşılıklı bir ilişki gören Jessop, bu iddiasını da şu şekilde açmaktadır: devlet, fordist rejime ücret ve emek piyasası ilişskilerini yöneterek, talep yaratıcı politikalarla arz ve talebi düzenleyerek yardımcı olur. Ekonomik dalgalanmalardan ve istikrarsız ekonomik düzenden 
firmaları korur ve onlara güven vererek ölçek ekonomilere ve yatırıma sevk eder. Bunların yanında sermaye ve tüketim malları endüstrisini birleştirir, alt-yapı projelerine yatırım yapar, ulusallaştırma ve birleştirme politikaları ile ölçek ekonomileri ilerletir. Kitlesel tüketimi sosyal transferlerle teşvik eder, buna ayrıca emek piyasasına ve toplu görüşmelere müdahale ile de yapar. Eş zamanda tam istihdam ve refah devleti politikaları da Fordist üretimi destekler. Kısacası devlet, sosyal problemleri çözerek, Fordist rejime istikrar kazandırır. Fordist rejim ise ortaya koyduğu muazzam büyüme ve büyümenin neden olduğu üretim ve istihdam ile Keynesyen refah devletini desteklemiştir. Sonuç olarak, Jessop'un iddiası, Keynesyen refah devletinin Fordist ekonomik gelişimi muhafaza etmek için şartlar geliştirdiği kadar, Fordist üretimin de, Keynesyen refah devletinin gelişimi için alan açtığıdır (1995: 256). Bu nedenle refah devletinin yaşadığı krizler, Fordist rejimi de zayıflatmış ve ortadan kaldırmıştır.

Fordist ve Keynesyen rejimin krizlerinden doğan Post-fordizm Jessop için Fordizm'den bir kopuş anlamına gelmemekte fakat devamlılık içinde bir kopuş olarak tanımlanmaktadır. Düşünür, Post-fordizm'de, Fordizm'e paralel 3 boyut olduğunu belirtmektedir: İş süreci olarak Post-fordizm, esnek makinelere ve sistemlere ve de uygun esnek işgücüne dayanan esnek üretim sürecidir. Bunun en yaygın görünüşü, enformasyon ve iletişim teknolojilerinin dayanağ 1 olan mikro-elektroniktir. Bu esneklikten kapitalistlerin beklentisi, yabancılaşmanın kitlesel işçi direncinin üstesinden gelmesi, artan farklı taleplerin karşılanması, Taylorizm ve kitlesel üretimdeki durgunluğun ve doygunluğun aşılmasıdır (Jessop, 1995: 258).

İkinci boyut ise istikrarlı bir makro ekonomik gelişim için Post-fordizmin esnek ve daimi yenilenen birikim kalıplarına dayanmakta olduğudur. Bu halde Post-fordist döngü şeması da şu şekilde oluşmaktadır: alan ekonomisine (economies of scope) ve inovasyon sürecine bağlı olarak üretkenlik artacaktır, vasıflı işçilerin ve hizmet sınıfının geliri artacaktır, gelirler sonucunda farklı ürün ve hizmetler için talepler artacaktır, teknoloji ve diğer yeniliklerin yükselişi ile kar artacaktır, esnek üretim ekipmanlarının süreçlerine ve ürünlerine dönük yatırım artacaktır.

Üçüncü boyut ücret ilişkilerinin vasıflı ve vasıfız işçi arasında farklılık göstermeye başlaması ve böylece emek piyasasında esneklik vurgusunun artmasıdır. Bu rejimde toplu pazarlık ulus düzeyinde değil, firma düzeyinde yapılmaya başlanır ve girişimcilik, hiyerarşik, iyi örgütlenmiş, bürokratikleşmiş büyük yapılardan yüzeysel, doğrusal olmayan esnek örgütlenme 
formlarına doğru kayar. Böylece, piyasanın taleplerine daha hızlı bir şekilde yanıt verebilir bir konuma ulaş1lır. Rekabet de fiyat üzerinden değil, farklılaştırılmış ürünler üzerinden müşterinin taleplerine yanıt verebilme kapasitesi üzerinden olacaktır. Üretim için gerekli olan finans ise özel, köksüz, uluslararası banka kredileri sayesinde olacaktır, devletin kredi imkânı uluslararası para ve piyasa tarafindan sınırlandırılacaktır.

Sonuç olarak Post-fordizm'in ekonomik düzenleme misyonu, Fordizme içkin eğilimlerden ortaya çıktığ 1 gibi, onun kriz eğilimlerini çözmek için de ortaya çıkmıştır. Bu nedenle, Postfordist sistemin yeni yapısal formları ve düzenleyici pratikleri, Fordist krizi çözmek için doğmuştur, diğer özellikler ise krizden sakınmak için, dolayısıyla bazı özellikleri defansif, bazıları ise ofansiftir (Jessop, 1995: 259). Ancak Jessop, Post-fordist rejime geçişin sadece kriz ile de açıklanmaması gerektiğini de vurgular ve geçişin diğer nedenlerini de sıralar: devletin, yeni teknolojik gelişimlerin ülke içinde yaygınlık kazanmasında sorumluluk alması, ekonomide uluslararasılaşmanın hızlanması ile devletin ulusal bir ekonomi gibi davranmaktan vazgeçmesi ve bunun için uluslararası işbirliği ve stratejik ittifaklar için yeni yasal formlar geliştirmesi, uluslararası sermaye ve kredi hareketlerinde reforma gitmesi, yeni telif hakları rejimi getirmesi. Ve son olarak belki de birinci derecede faal olan unsur, küresel düzlemde Fordist paradigmadan, Post-fordist paradigmaya geçilmesidir.

Post-fordist paradigmaya denk gelen devlet düzeni ise artık Keynesyen refah devleti değil, Schumpeterian iş bulucu (workfare) devletidir (Jessop, 1994: 263). Jessop'a göre bu devletin hedefi, arz yönlü müdahalelerde bulunarak, ulusal ekonominin yapısal rekabet güçlerini geliştirmek ve bunu ürünleri, süreci geliştirerek ve örgütsel yeniliklerle başarmaktır. Tabi bunun yanında aynı devlet, sosyal politikaları da, piyasanın esneklik talepleri ve uluslararası rekabet sınırlandırmalarını da göz önünde bulundurarak iğdiş edecektir. Schumpeterian devlet bu haliyle Keynesyen devletten bir kopuşu ifade etmektedir, zira burada tam istihdam, uluslararası rekabet tarafından ezilirken, yeniden paylaşımcı refah hakları da, sosyal politikanın üretken yeniden düzenlemesi karşısında kaybolmaktadır. Tüm bu değişimin sonucunda ulusal devlet de yarılmış ve başka bir forma kavuşmuştur. Yeni oluşan bu form çelişkili bir yapı arz etmektedir: bir taraftan ulus devlet hala politik olarak önemli ve egemenlik haklarına sahiptir; fakat diğer taraftan devlet uluslararası sermayenin talepleri ve esnek üretime dönük bask1 nedeniyle sınırlandırılmış bir halde bulunmaktadır. Devletin bu özerklik kaybı ulus üstü koordinasyon ihtiyacı yarattığı gibi, ulus devlet içinde de daha alt yönetsel kademelerde bir 
canlılığa neden olmuştur. Öyle ki, devlet çoğu kapasitesini gittikçe artan sayıda, pan-regional, plurnational ve uluslararası örgütlere kaydırmıştır; diğerleri ise devlet içindeki yerel ve bölgesel yönetişim alanlarına bırakılmıştır (Jessop, 1994: 265).

Post-fordist paradigmanın şekillendirdiği Schumpeterian devletin bir diğer niteliği yönetimin merkeziliğinden, yönetişimin merkezsizleşmiş biçimine doru kayıştır. Bu gelişme, ekonomik ve toplumsal ilişkilerin yönetiminde resmi devlet aygıtlarının önceliğini veri kabul eden bir anlayıştan, resmi, yarı-kamusal ve hükümet dışı örgütler arasında değişik biçim ve düzeylerde ortaklık kurulması gerçekliğini veri kabul eden anlayışa geçişi içermektedir (Jessop, 2005c: 319). Bu aynı zamanda, egemen devletlerde tipik olan yukarıdan aşağı hiyerarşik siyasi örgütlenmelerden, örgütler arası ilişkilerin kendi kendini örgütlemesini teşvik etmek ve yönlendirmek üzerine vurgu yapmaya başlamayı da kapsamaktadır. Şebekelerin, ortaklıkların ve diğer ekonomik ve siyasi yönetişim modellerinin geniş alanında, resmi aygıtlar en fazla primus inter pares olabilecektir. $\mathrm{Bu}$ anlamda, devlet müdahalesi tabiatı gereği daha az hiyerarşik, daha az merkeziyetçi ve daha az ekonomik nitelikli müdahale özelliği taşıma eğiliminde olacaktır. Bu genel eğilim, egemen devlet tarafından yukarıdan aşağıya dayatılan zorunlu koordinasyondan, karş1lıklı bağımlılık ve bilginin bölüşülmesine ve düşünülmüş pazarlıklar ve karşılıklı öğrenmeye dönüş ile bağlantılıdır (Jessop, 2005c: 321).

Devletin bu yeni birikim rejimine bağlı olarak kazandığı bir diğer nitelik yukarıda da belirttiğimiz üzere, workfare’e bağlı olarak rekabet güdüsüdür. Schumpeterian devletin küresel çağda temel hedefi, ulusal ekonominin yurt içinde dengeli performans göstermesinden uzaklaşarak, en geniş anlamıyla ulusal rekabet gücünü artırmaktır. Bu kaygıyla devletler, ürün, işlem, örgüt ve piyasa yenilikleri üzerinden gerçekleştirilen arz yönlü müdahalelerle ulusal ekonominin rekabet gücünü olabildiğince artırmayı hedeflemektedirler; devlet artık ulusal bir proje olarak tam istihdamın değil, fakat bölgesinde özel sektörün istihdam yaratabilmesine dönük teknik, hukuki yeniliklerin peşindedir (Jessop, 2005c: 323). Sınır-ötesi işbirliği ve stratejik ittifaklar için yeni yasal biçimler oluşturmak, uluslararası para ve kredi sistemlerini yeniden düzenlemek, teknoloji transferini teşvik etmek, ticari anlaşmazlıkları çözüme bağlamak, yeni uluslararası mülkiyet hakkı rejimi tanımlamak ve emek göçü için yeni düzenleme biçimleri geliştirmek devletin asli fonksiyonları haline gelmiştir (Jessop, 2009: 201). 
Rekabetçi devletin bir diğer niteliği de inovasyon ve girişimcilik konularındaki hassasiyetidir. Teknolojik istihbarat toplamakla ilgilenen, bağımsız teknolojik kapasiteler yaratılmasına yardımcı olan ve inovasyon kapasiteleri, teknik yeterlilik ve teknoloji transferini destekleyen rekabet devleti, aslında mümkün olduğu kadar çok firma ekonomisinin özel departmanlarında yürüttüğ̈̈ ar-ge faaliyetleriyle yaratılan yeni teknolojik firsatlardan faydalanılmasını amaçlar (Jessop, 2009: 203). İlk olarak, girişimleri doğrudan destekleyen var olan ya da potansiyel kurumları ve yapıları ve ikinci olarak da, girişim için uygun bir iklimi sürdüren kurumları ve yapıları geliştirir. Yine inovasyon temasına bağlı olarak bilgi tabanlı ekonominin gerekirleri olan patent, telif hakk1 ve lisans gibi hukuki düzenlemeleri takip eder (Jessop, 2009: 207).

Tüm bunları dikkate aldığımızda post-fordist rejimin şekillendirdiği toplumsal hayatın artık ekonomi-dışı alanlara sahip olmadığını görüyoruz. Yaşamın tüm veçheleri bu rekabetçi rejim içinde ekonomiye dâhil edildiği için, devlet de toplumun tamamını uluslararası rekabet gayesi ile yönlendirmeye meyl eder. Fakat bu genişleyen müdahale sahası, devletin giderek acilleşen ekonomik zorunluluklara verdiği tepkileri, genel politik meşruiyetin ve toplumsal yapışmanın güvenceye alınması yönündeki daha genel taleplerle bağdaştırmasının daha da güçleştiği anlamına gelmektedir (Jessop, 2009: 210).

\section{Sonuç}

Öncelikle şunu diyebiliriz ki, Jessop devlet konusunda kendisinden önce gelen devlet kuramcılarına göre çok daha ayrıntılı, kompleks bir analize girişmiştir. Bunun nedeni ise ele aldığ 1 devletin içinde bulunduğu post-fordist paradigmanın yeniliğinden kaynaklanan belirsizliktir. Hali hazırda olmakta, gelişmekte bulunan bu üretim tarzının içinde yer alıp, ona dair yorumlarda bulunmak ilk elde yöntemsel bir zorluk taşımaktadır. Bu zorluktan dolayı Jessop, diğer disiplinlere başvurarak yeni üretim paradigmasının şekillendirdiği devleti açıklayabilecek kavramlar devşirmiştir: yönetimsellik, yapısal seçicilik ve autopoiesis. Bu yeni kavramlar ışığında devleti stratejik mücadele alanı olarak tanımlayan ve daimi olarak yeniden inşa edilen ilişkiler bütünü olarak gören Jessop, diğer devlet kuramcılarına göre oldukça farklı bir konuma yerleşmiştir. Onun için soyut, deney öncesi bir devlet formu yoktur, devlet hegemonik projelerin ve birikim stratejilerinin yarattığ 1 bir formdur ve bu form post-fordist üretim tarzı ile çok daha belirgin bir hal almıştır. Bir diğer deyişle sivil toplumun dışında bir devlet ve devletin dişında bir sivil toplum yoktur, bu haliyle Jessop, Gramsci'nin sadık bir 
öğrencisidir. Yine post-fordist paradigmaya bağlı olarak devlet, düşünür için keynesyen niteliklerinden sıyrılarak, rekabetçi, çalıştırmacı bir niteliğe bürünmüş, toplumun her alanında etkisi daha hissedilir olmuş, sivil toplumla örtüşmüştür.

Görüldüğü üzere Jessop, post-fordist rejim ve devlet ilişkisinde değer yargısız yaklaşmış, sadece ilişkiyi ayrıntılı bir şekilde açmakla yetinmiştir. Devletin, iktisadi ve sosyal alanda diğer sivil ve yar1-kamusal aktörlerle ilişkiye girme zorunluluğunu ne Lipietz gibi demokratik bir hamle, ne de Tomaney gibi kapitalizmin yeni bir yüzü olarak okumaktadır. Yine devletin, yerele ve uluslararası platforma açılmasını, ilerici bir aşama olarak değil, fakat üretim tarzının bir gereği olarak yorumlamaktadır. Bu bağlamda Jessop'u yönetimselliğinden dolayı, kitleleri daha ön plana çıkaran bir yorumcu olarak değerlendirenler kanaatimce yanılmaktadırlar; zira Jessop tüm bu analizlerinin içinde mevcudu dönüştürecek olan faili ortadan kaldırmıştır. 


\section{Kaynakça}

Amin, Ash (1995), "Post-Fordism: Models, Fantasies and Phantoms of Transition", içinde Post-Fordism, (ed. Amin Ash), Blackwell Pub, Cambridge.

Belek, İlker (1999), Post Kapitalist Paradigmalar, Sorun Yayınları, İstanbul.

Güney, Atilla (2004), "Kapitalizmin Krizi ve Devlet Kuramı: Bob Jessop Üzerine Bir Değerlendirme", Praksis Dergisi, Say1:9, Syf: 357-377.

Güney, Atilla (2006), “Bob Jessop'da Yönetişim Kavramı: Stratejik İlişkisel Devlet Biçiminden Yönetişim Biçimine”, Memleket Siyaset-Yönetim Dergisi, Sayı:1, Syf: 153-171.

Jessop, Bob (1995), "Post-Fordism and the State", içinde Post-Fordism, (ed. Amin Ash), Blackwell Pub, Cambridge.

Jessop, Bob (2005a), "Kapitaslit Devlete Dair Yeni Kuramlar”, içinde Hegemonya, PostFordizm ve Küreselleşme Ekseninde Devlet, (ed. Betül Yarar, Alev Özkazanç), İletişim Yayınları, İstanbul.

Jessop, Bob (2005b), "Siyasi Strateji Olarak Devlet", içinde Hegemonya, Post-Fordizm ve Küreselleşme Ekseninde Devlet, (ed. Betül Yarar, Alev Özkazanç), İletişim Yayınları, İstanbul.

Jessop, Bob(2005c), "Ulusal Ekonomik ve Ulusal Devletin Geleceğini Anlatılamak? Düzenlemenin Yeniden Haritalandırılması ve Yönetişimin Yeniden İcadı Üzerine Düşünceler”, Hegemonya, Post-Fordizm ve Küreselleşme Ekseninde Devlet, (ed. Betül Yarar, Alev Özkazanç), İletişim Yayınları, İstanbul.

Jessop, Bob (2009), Kapitalist Devletin Geleceği, (çev. Ahmet Özcan), Epos Yayınları, Ankara. 
Lipietz, Alain (1992), Towards A New Economic Order: Postfordism, Ecology and Democracy, Oxford Press, New York.

Lipietz, Alain (1995), “Post-Fordism and Democracy”, içinde Post-Fordism, (ed. Amin Ash), Blackwell Pub, Cambridge.

Sabel, Charles (1995), "Flexible Specialization and the Re-emergence of Regional Economies", içinde Post-Fordism, (ed. Amin Ash), Blackwell Pub, Cambridge.

Tomaney, John (1995), “A New Paradigma of Work Organization and Technology?”, içinde Post-Fordism, (ed. Amin Ash), Blackwell Pub, Cambridge. 